\title{
REMOVING AGGRESSIVE CARBON DIOXIDE FROM WATER USING MELAPHYRE BED
}

\author{
Magdalena M. Michel' ${ }^{1}$, Tadeusz Siwiec ${ }^{1}$, Lidia Reczek ${ }^{1}$, Celina Duda ${ }^{1}$ \\ 1 Department of Civil Engineering, Faculty of Civil and Environmental Engineering, Warsaw University of Life \\ Sciences - SGGW, Nowoursynowska 159, 02-776 Warszawa, Poland \\ * Corresponding author's e-mail: magdalena_michel@sggw.pl
}

Received: 2017.06.22

Accepted: 2017.08.01

Published: 2017.09.01

\begin{abstract}
The experiment was based on filtration of the highly aggressive water through the melaphyre bed. The quartz bed was non-reactive reference material. The aim of this work was to determine the ability of the melaphyre to remove aggressive $\mathrm{CO}_{2}$ during the chemical reaction. It was noted that a decrease of acidity of the filtrate in comparison to the feed and an increase of its alkalinity and $\mathrm{pH}$. It was calculated that until the moment of exhaustion of the de-acidifying properties of the melaphyre, maximum amount of bound $\mathrm{CO}_{2}$ added to the water was $29.7 \mathrm{~g} \mathrm{CO}_{2} / \mathrm{L}$ of the bed, and maximum amount of the aggressive $\mathrm{CO}_{2}$ removed from the water was $33.3 \mathrm{~g} \mathrm{CO}_{2} / \mathrm{L}$ of the bed. Regarding very high content of the aggressive $\mathrm{CO}_{2}(116 \mathrm{mg} / \mathrm{L}$ average $)$ in the feed only $28.76 \%$ of this component was subject to transformation into bound and affiliated $\mathrm{CO}_{2}$ in the filtrate. For the melaphyre bed the $\mathrm{CO}_{2}$ loss from the experiment system following from desorption was $7.80 \%$ of the total load of $\mathrm{CO}_{2}$ added with the feed. On the quartz bed the loss was slightly lower $4.56 \%$.
\end{abstract}

Keywords: water de-acidification, carbon dioxide, melaphyre

\section{INTRODUCTION}

Water containing excessive carbon dioxide is aggressive and causes increased damage to water supply network, leading to financial losses and generates a lot of technological problems in its treatment processes [Kowal, ŚwiderskaBróż 2009; Reczek et al. 2014; Zymon 2007]. It is known that improper quality of water used in the supply network systems and industry is an important factor leading to corrosion [Wolska, Świderska-Bróż 2008]. Unfortunately, in some cases the waterworks are supplied with chemically unstable water, which reveals corrosiveness or aggressiveness [Wolska, Mołczan 2015]. The factor which causes an absence of chemical stability of water is the presence of aggressive carbon dioxide $\left(\mathrm{CO}_{2}^{a g r}\right)$, which is typical for ground water. In technological systems of aggressive water treatment mainly the method of physical removal of $\mathrm{CO}_{2}{ }^{a g r}$ based on its desorption to the air is used [Kowal, Świderska-Bróż 2009]. Issuing from the carbon-calcium balance, the form of occurrence of carbon dioxide depends on the water $\mathrm{pH}$ : free carbon dioxide $\left(\mathrm{CO}_{2}^{f}\right)$, including $\mathrm{CO}_{2}{ }^{a g r}$, dominates when water $\mathrm{pH}$ is acidic; if it is alkaline, carbon dioxide is changed to bind in the form of carbonates and bicarbonates as an alkalinity $\left(\mathrm{CO}_{2}{ }^{a l c}\right)$ [Gomółkowie 1992]. The method of chemical de-acidification is based on these changes. Water with very low alkalinity requires the use of chemical de-acidification, based on dosing alkaline to the water or filtration of the water through de-acidifying deposits. Soft water and very soft water requires de-acidification and re-mineralization, which effectively prevents it from having corrosive properties [Jaeger et al. 2006]. In water treatment technology, filter beds are used in which one of the layers or the whole filling of the filter consists of mineral materials, which enter into a reaction with $\mathrm{CO}_{2}{ }^{a g r}$ contained in the water. Among the de-acidifying deposits, it 
is possible to distinguish those which consist of calcium carbonate: marble, Hydrolit-Ca, HydroCalcit, or those which consist of calcium carbonate and magnesium oxide: calcined dolomite, Magno-Dol and Akdolit-Gran. Corosex is an another commercial de-acidifying material, which is fabricated granulate of magnesium oxide. Alkaline compounds in the form of sodium hydroxide or sodium carbonate, as well as mineral materials, such as serpentine, olivine or wollastonite are used for $\mathrm{CO}_{2}$ capture [Kordylewski et al. 2013].

Mineral material with proven ability to alkalize water is melaphyre, it reveals abilities to de-acidify and remineralise desalinated water in the RO process on the level similar to Hydrolit$\mathrm{Ca}$ [Michel et al. 2015]. Melaphyre heating at the temperature of $900{ }^{\circ} \mathrm{C}$ leads to a significant increase of its alkaline properties [Michel et al. 2016]. Melaphyre is a volcanic rock dating back to Palaeozoic [Żaba 2003]. It belongs to alkaline rocks, and its chemical composition includes compounds of silicon, aluminium, iron, sodium, potassium, calcium, magnesium and titanium [Murzyn, Dyczek 2009; Stolecki et al. 2011]. Main crystalline components which build melaphyre are plagioclase, pyroxenes, olivine and quartz [Murzyn, Dyczek 2009; Stolecki, Murzyn 2011]. Melaphyre is not currently used in water treatment technology. Research on its application is still in progress. One of the tested solutions is the use of this material to de-acidify water containing aggressive $\mathrm{CO}_{2}$. That is why the aim of this work was to determine under flow-through conditions melaphyre abilities to react with aggressive $\mathrm{CO}_{2}$ contained in water and to characterize properties of the water which was de-acidified in this way.

\section{MATERIALS AND METHODS}

In the research melaphyre with granulation of $0.5-1.0 \mathrm{~mm}$ was used, it comes from the mine in Tłumaczów (Lower Silesian Voivodeship, district of Kłodzko, Radków municipality). As a reference material, which does not react with $\mathrm{CO}_{2}$, aquarium quartz with granulation of $0.8-1.0 \mathrm{~mm}$ was used. The materials were prepared in filtration columns by washing out dust fraction, supplying tap water from the bottom to the top and maintaining 30\% expansion within 10 minutes. Then, the beds were rinsed with small amount of distilled water. Aggressive water was prepared by introducing compressed $\mathrm{CO}_{2}$ through a porous stone to the water which was in the open container. Water de-mineralized in the process of lowpressure reverse osmosis was used.

The experiment was based on gravitational filtration of aggressive water through melaphyre and sand beds with a constant speed of $10 \mathrm{~m} / \mathrm{h}$. The melaphyre and the sand were located in laboratory models of filters whose diameter was 20 $\mathrm{mm}$. Thickness of each of the beds was $700 \mathrm{~mm}$, and the supportive layer was $20 \mathrm{~mm}$ (glass wool). The feed water was collected in an open container and was supplied to the filter with a slow stream through a gravity flow at the bottom of the container. The filtrates passing through the beds were collected in one hour intervals - instantaneous samples were collected. At the same time samples of water which was supplied onto the filters were also collected. In the samples of water supplied and discharged from the filter $\mathrm{pH}$, total alkalinity and total acidity were analysed. In order to measure $\mathrm{pH}$, a potentiometric method was used. However, total alkalinity and total acidity were measured by alkacymetric titration, accordingly: by standard $\mathrm{HCl}$ solution in the presence of methyl orange, and by standard $\mathrm{NaOH}$ solution in the presence of phenolphthalein. Free carbon dioxide $\mathrm{CO}_{2}^{f}[\mathrm{mg} / \mathrm{L}]$ content in the water was calculated on the basis of the results of total acidity measuring $[\mathrm{mval} / \mathrm{L}]$, multiplied by Molar mass of $\mathrm{CO}_{2}$. Concentration of the affiliated $\mathrm{CO}_{2}$ aff $[\mathrm{mg} / \mathrm{L}]$ was calculated from formula (1) [Gomółkowie 1992]:

$$
\left[\mathrm{CO}_{2}^{\text {aff }}\right]=44 \cdot k\left[\mathrm{HCO}_{3}^{-}\right]^{3}
$$

where $k$ is calcium-carbonate balance constant, which is $1 / 160$ at the temperature of $20^{\circ} \mathrm{C}_{,} \mathrm{HCO}_{3}{ }^{-}$ is water alcalinity $[\mathrm{mval} / \mathrm{L}]$, and 44 is Molar mass of carbon dioxide [ $\mathrm{g} / \mathrm{mol}$ ]. Concentration of aggressive $\mathrm{CO}_{2}{ }^{a g r}$ was calculated as a difference of $\mathrm{CO}_{2}^{f}$ and $\mathrm{CO}_{2}^{a f f}$. Bounded $\mathrm{CO}_{2}^{\text {alc }}$ was calculated on the basis of the results of measurement of total alkalinity $[\mathrm{mval} / \mathrm{L}]$, multiplied by equivalent weight of $\mathrm{CO}_{2}$. Total $\mathrm{CO}_{2}{ }^{t}$ was calculated as a sum of $\mathrm{CO}_{2}^{f}$ and $\mathrm{CO}_{2}{ }^{\text {alc }}$.

\section{RESULTS AND DISCUSSION}

Melaphyre had properties to de-acidification and remineralization desalinated water. The parameters describing its properties are presented in Table 1. Low alkalinity of water is dictated by its low salinity (demineralised water). The feed 
Table 1. Parameters of feed water and filtrate from melaphyre bed

\begin{tabular}{|l|c|c|c|c|c|c|c|}
\hline \multirow{2}{*}{ Parameter } & \multirow{2}{*}{ Unit } & \multicolumn{3}{c|}{ Feed water } & \multicolumn{3}{c|}{ Filtrate } \\
\cline { 3 - 9 } & & average & median & SD & average & median & SD \\
\hline $\mathrm{pH}$ & - & 5.04 & 5.05 & 0.21 & 6.70 & 6.67 & 0.25 \\
\hline total alkalinity & $\mathrm{mval} / \mathrm{L}$ & 0.37 & 0.33 & 0.13 & 1.75 & 1.63 & 0.46 \\
\hline total acidity & $\mathrm{mval} / \mathrm{L}$ & 2.63 & 2.70 & 0.64 & 1.73 & 1.77 & 0.41 \\
\hline bounded $\mathrm{CO}_{2}^{\text {alc }}$ & $\mathrm{mg} / \mathrm{L}$ & 8.2 & 7.2 & 2.9 & 38 & 26 & 10 \\
\hline aggressive $\mathrm{CO}_{2}$ agr & $\mathrm{mg} / \mathrm{L}$ & 116 & 119 & 28 & 74 & 75 & 17 \\
\hline
\end{tabular}

contained too little of carbon dioxide bound in the form of carbonates and hydrocarbonates $\left(\mathrm{CO}_{2}{ }^{a l c}\right)$. Saturating it with gas caused significant increase of acidity, which was due to a large amount of $\mathrm{CO}_{2}^{f}$. It is necessary to mention that regarding low alkalinity of the water, the amount of $\mathrm{CO}_{2}$ aff was marginal $(<0,1 \mathrm{mg} / \mathrm{L})$ and $\mathrm{CO}_{2} \approx \mathrm{CO}_{2}{ }^{a g r}$. That is why in the latter part only $\mathrm{CO}_{2}^{\text {agr }}$ will be investigated. As a result of filtration of water through melaphyre bed, a reaction of $\mathrm{CO}_{2}{ }^{a g r}$ with the melaphyre components took place, as evidenced by decrease of acidity of the filtrate in comparison to the feed (Table 1). The products of reaction were dissolved in water, therefore the increase of $\mathrm{pH}$ and alkalinity in the filtrate were noted (Figure 1). The presented graphic results of the titration analysis distinctly shows scattering of total acidity measurements in the samples of the feed and filtrated water. This is because of low accuracy of $\mathrm{CO}_{2}{ }^{a g r}$ measurements in comparison to $\mathrm{pH}$ and $\mathrm{CO}_{2}{ }_{2}^{2}$ measurements, which was mentioned in the work of Dąbrowski et al. [2008]. During the experiment slow, but not complete exhaustion of de-acidifying properties of melaphyre occurred, which is presented in Figure 2. The figure summarized: (i) a tendency of changes in the growth rate of $\mathrm{CO}_{2}^{\text {alc }}$ in the water in the function of the summarized quantity of $\mathrm{CO}_{2}^{\text {alc }}$ added to the water; (ii) tendency of changes in the decrease of $\mathrm{CO}_{2}{ }^{a g r}$ in the water in the function of the summarized quantity of $\mathrm{CO}_{2}^{a g r}$ removed from the water. The dependencies were written as linear functions in directional form, for which zero function places were calculated. It allowed to determine the maximum total quantities of $\mathrm{CO}_{2}^{a g r}$ removed from the water and $\mathrm{CO}_{2}$ alc added to the water for the point in which $\mathrm{CO}_{2}{ }^{a g r}$ stops being bounded. Accordingly the results were: $6523 \mathrm{mg} \mathrm{CO}_{2}^{\text {alc }}$ and

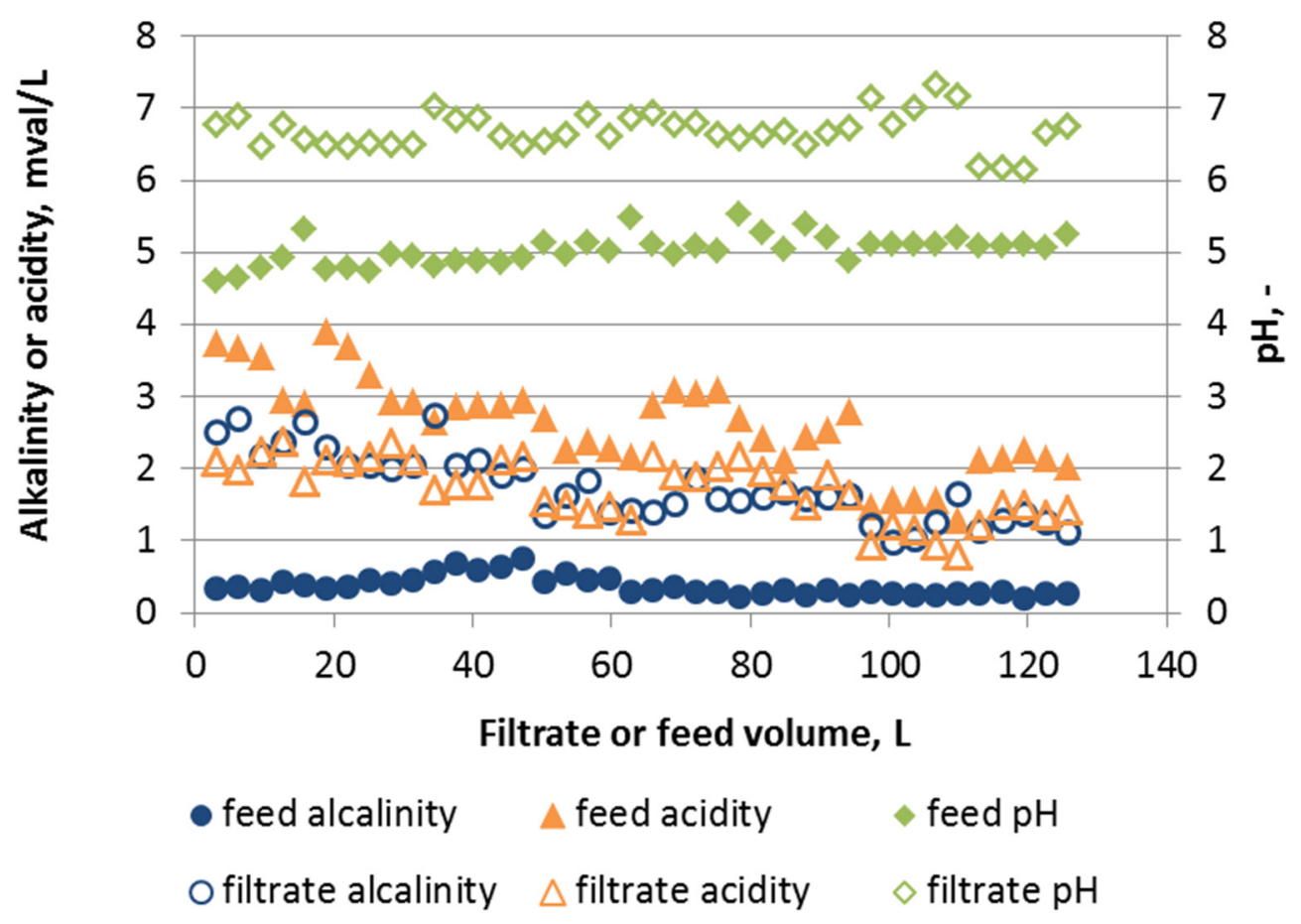

Figure 1. Total alkalinity, total acidity and the water $\mathrm{pH}$ before and after the contact with the melaphyre bed in the function of filtered water volume. 


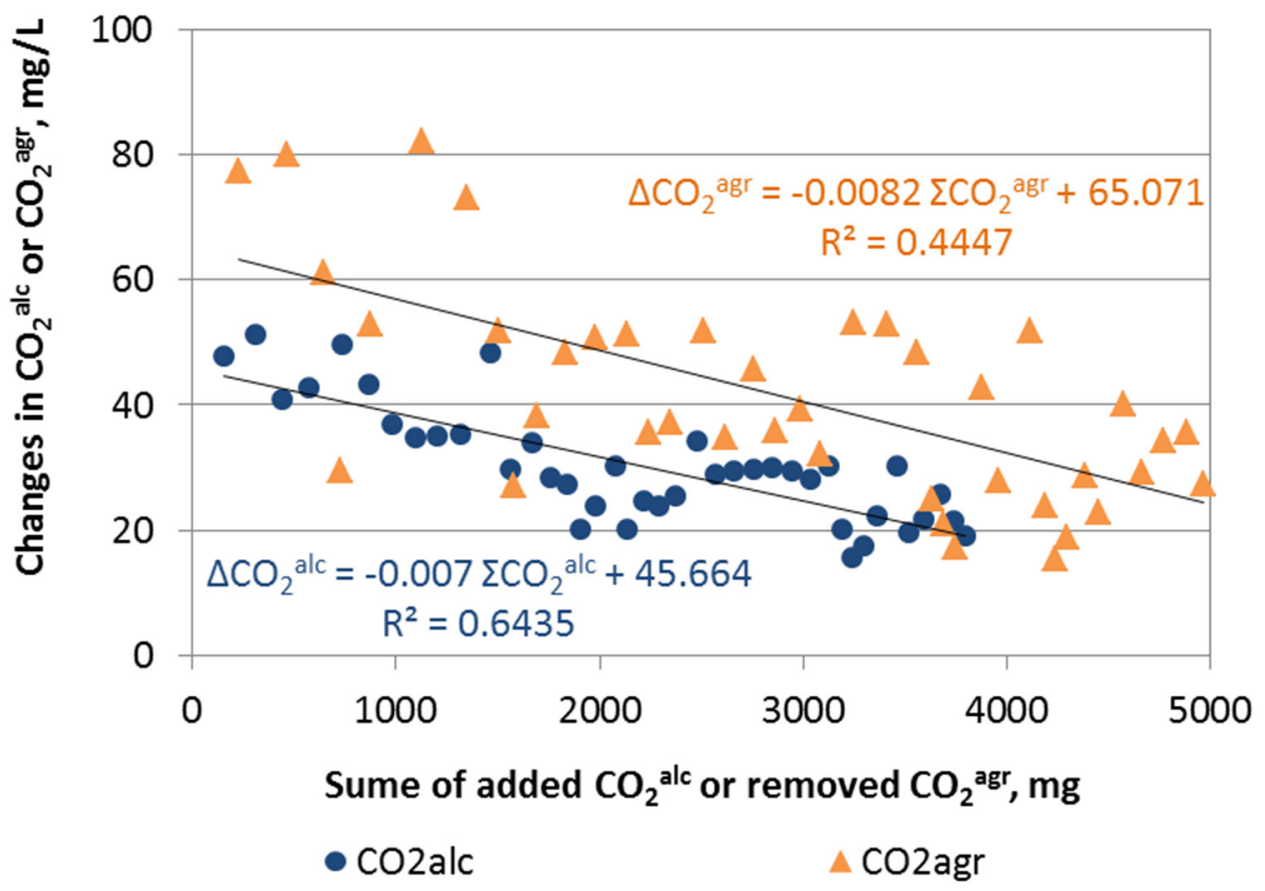

Fig. 2. Differences between concentration of $\mathrm{CO}_{2}{ }^{\text {alc }}$ or $\mathrm{CO}_{2}{ }_{2}^{a g r}$ in the feed or in the filtrate in the function of summarized load of $\mathrm{CO}_{2}{ }^{a l c}$ added to the water or $\mathrm{CO}_{2}{ }^{a g r}$ removed from the water.

$7935 \mathrm{mg} \mathrm{CO}{ }_{2}^{a g r}$. When converted to unit volume of the melaphyre bed, maximum quantity of the $\mathrm{CO}_{2}{ }^{a g r}$ removed from the water until the moment of the exhaustion was $36.1 \mathrm{~g} \mathrm{CO}_{2} / \mathrm{L}$ of the material. However, maximum quantity of the $\mathrm{CO}_{2}^{\text {alc }}$ added to the water until the moment of the deposit exhaustion was $29.7 \mathrm{~g} \mathrm{CO}_{2} / \mathrm{L}$ of the deposit. In a similar experiment described in the work of Michel et al. [2015], the exhaustion of properties of the melaphyre were not observed, which followed from a smaller load of $\mathrm{CO}_{2}^{\text {agr }}$ entered on the bed (a shorter filtration cycle and a lower concentration of $\mathrm{CO}_{2}{ }^{a g r}$ in the feed water were used). Decrease of de-acidifying ability is also typical for dolomite whose exploitation requires complementation with a portion of new material.

During the experiment, based on filtration of water containing a large amount of $\mathrm{CO}_{2}{ }^{a g r}$, its loss from the experimental system took place. That is why the total load of $\mathrm{CO}_{2}{ }^{t}$ added with the feed to the melaphyre bed and total load of $\mathrm{CO}_{2}^{t}$ discharged with the filtrate were compared. A similar comparison was performed for the measurements carried out in the reference experiment, where the filtration filling was high purity quartz sand without any additives which can react with $\mathrm{CO}_{2}$. The results in the form of sum dependences are presented in Figure 3. In the ideal conditions, the amount of added and removed $\mathrm{CO}_{2}{ }_{2}^{t}$ from the nonreactive filter should balance, and the dependence should be linear, directly proportional $y=x$ with a slope equals 1, which is marked in Figure $3 \mathrm{a}, \mathrm{b}$ with a black line. The results of the experiment carried out on the quartz bed are described with the equation of the line (marked blue in Figure $3 \mathrm{a}$ ), which slope is 0.9544 . It shows that $4.56 \%$ of $\mathrm{CO}_{2}^{t}$ load added in the feed did not leave the model in the filtrate. Supposing that the pure quartz sand did not react with $\mathrm{CO}_{2}$, it can be assumed this value as part of $\mathrm{CO}_{2}{ }^{t}$ which during the experiment was subject to desorption to the ambient air. In the case of the melaphyre bed (Figure $3 \mathrm{~b})$ the slope was of a lower value (0.9220), that is $7.8 \%$ of $\mathrm{CO}_{2}^{t}$ load of the feed was not found in the filtrate. This difference can follow from a longer time of the experiment of the melaphyre or binding of $\mathrm{CO}_{2}$ with the melaphyre compounds in the form that cannot be flushed from the material. Melaphyre is a rock with a more diverse mineral composition than quartz sand. Although, in the both experiments the dependences have similar trend, and the values of non-balanced $\mathrm{CO}_{2}$ are alike.

Similar comparison was made for the sum of $\mathrm{CO}_{2}{ }^{a g r}$ in the feed and the filtrate for the quartz sand and melaphyre - marked red in Figure 3 a, b. In the case of the quartz bed the slope of the line in the $\mathrm{CO}_{2}{ }^{a g r}$ series is almost identical to the slope in the $\mathrm{CO}_{2}{ }_{2}^{t}$ series. It confirmed the lack of reaction of the aggressive carbon dioxide with the 

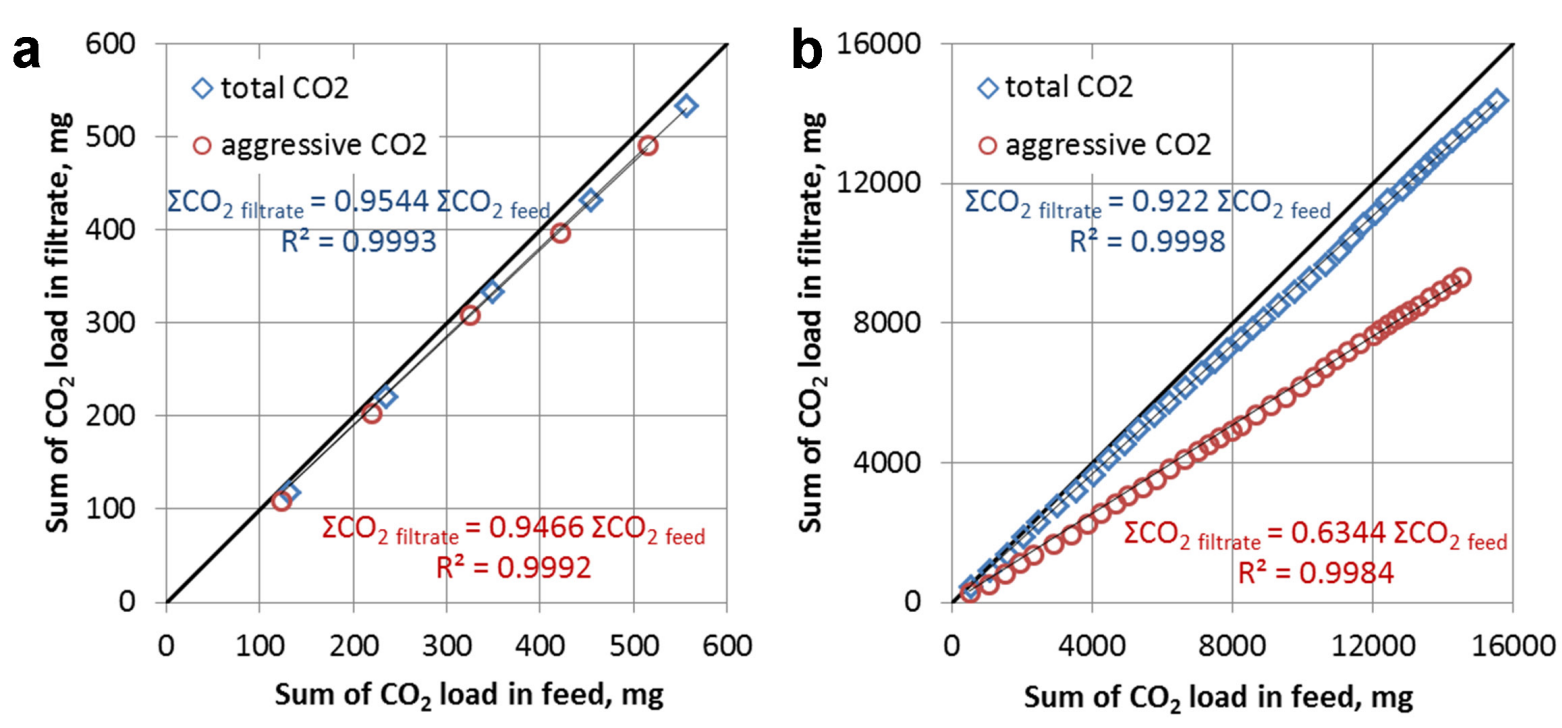

Figure 3. Dependence between sum content of total and aggressive carbon dioxide in the feed and the filtrate for the quartz (a) and melaphyre (b) beds.

filtration material. The results for the melaphyre are different. The slope is 0.6344 , thus $36.56 \%$ of $\mathrm{CO}_{2}{ }^{a g r}$ added to the melaphyre does not leave the filtration bed at the same form. Considering 7.8\% loss of $\mathrm{CO}_{2}{ }^{t}$ in the experiment, it is possible to calculate that $28.76 \%$ of $\mathrm{CO}_{2}{ }^{a g r}$ in the feed was subject to transformation to $\mathrm{CO}_{2}^{\text {alc }}$ and $\mathrm{CO}_{2}^{\text {aff }}$ in the filtrate. It is determined by a percentage of $\mathrm{CO}_{2}{ }^{a g r}$ transformation to the forms of bound and affiliated which take place as a result of dissolving alkaline components of the melaphyre and flushing them with water.

\section{CONCLUSIONS}

Filtration of aggressive water through the melaphyre bed enables its complete de-acidification due to reaction of $\mathrm{CO}_{2}{ }^{a g r}$ with the components of the rock (probably the carbonates) and transform it to the bound form. It was accompanied by a decrease of acidity of the filtrate in comparison to the feed and by an increase of its alkalinity and $\mathrm{pH}$. During the experiment a slow exhaustion of the melaphyre properties was observed, which is typical for de-acidifying materials. A huge content of $\mathrm{CO}_{2}{ }^{a g r}$ and low alkalinity disabled complete de-acidification of the water in the experiment conditions - the time of the contact of the water with the bed was too short for the full reaction (4 minutes).

I the experiment the sum load of $\mathrm{CO}_{2}{ }^{a g r}$ transformed in the bound and affiliated form
$\left(\mathrm{CO}_{2}^{a l c}+\mathrm{CO}_{2}^{\text {aff }}\right)$ was $20.3 \mathrm{~g} \mathrm{CO}_{2} / \mathrm{L}$ of the melaphyre bed. However, it is necessary to point out that this is not a complete of de-acidification capacity because the ability to react with $\mathrm{CO}_{2}$ was not subject to exhaustion. It was stated by extrapolating that maximum amount of $\mathrm{CO}_{2}^{\text {alc }}$ added to the water until the moment of the melaphyre exhaustion was $29.7 \mathrm{~g} \mathrm{CO}_{2} / \mathrm{L}$ of the bed. Taking into account $7.8 \%$ loss of $\mathrm{CO}_{2}{ }^{t}$ in the feed, the maximum amount of $\mathrm{CO}_{2}{ }^{a g r}$ removed from the water until the material exhaustion can be assumed as $33,3 \mathrm{~g} \mathrm{CO}_{2} / \mathrm{L}$ of the bed.

On the basis of the analysis of the curves summing the content of $\mathrm{CO}_{2}^{t}$ in the feed and the filtrate in the sand and melaphyre beds, the amount of the lost $\mathrm{CO}_{2}$ was calibrated in the experiment to 4.56 and $7.8 \%$. Taking into account series of $\mathrm{CO}_{2}{ }^{\text {agr }}$, it was calculated that $28.76 \%$ of $\mathrm{CO}_{2}{ }^{\text {agr }}$ from the feed was subject to transformation into $\mathrm{CO}_{2}^{\text {alc }}$ and $\mathrm{CO}_{2}$ aff in the filtrate.

\section{REFERENCES}

1. Dąbrowski W., Buchta R., Dąbrowska B., Mackie R.I. 2010. Calcium carbonate equilibria in water supply systems. Environment Protection Engineering, 36(2), 75-94.

2. Gomółkowie B. and E. 1992. Laboratory exercises of water chemistry. Wydawnictwo Politechniki Wrocławskiej, Wrocław. (in Polish)

3. Jaeger Y., Oberti S., Guichot L., Baron J. 2006. Evaluation of treatment methods to reduce the corrosivity of soft waters. Water Science and Technol- 
ogy: Water Supply, 6(5), 101-110.

4. Kordylewski W., Sawicka D., Falkowski T. 2013. Laboratory tests on the efficiency of carbon dioxide capture from gases in $\mathrm{NaOH}$ solutions. Journal of Ecological Engineering, 14(2), 54-62.

5. Kowal A.L., Świderska-Bróż M. 2009. Water treatment. PWN, Warszawa. (in Polish)

6. Michel M.M., Siwiec T., Reczek L., Wereda N. 2015. Water deacidification using malaphire, dolomite and hydrolite. Instal, 362(5), 56-59. (in Polish)

7. Michel M. M., Reczek L., Siwiec T., Wereda N. 2016. Effect of heat treatment on water deacidifying properties of melaphyre, Ochrona Środowiska, 38(3), 49-52. (in Polish)

8. Murzyn P., Dyczek J. 2009. The role of melaphyre as a raw material additive in technology of ceramic building materials. Materiały Ceramiczne, 61(1), 16-20. (in Polish)

9. Reczek L., Michel M.M., Siwiec T., Nowak P. 2014. Deacidification of water taken in the water supply station in Sreoczyn. Instal, 356(11), 76-80. (in Polish)

10. Stolecki J., Murzyn P. 2011. Influence of firing conditions on properties of ceramic materials made of carbon slate, Materiały Ceramiczne, 63(1), 74-79.

11. Stolecki J., Murzyn P., Brylska E. 2011. Characteristics of carbon clay shale from the Lublin Coal Basin (LCB) and technological additives designed for the clinker production. Part I. Materiały Ceramiczne, 63(1), 175-185. (in Polish)

12. Wolska M., Świderska-Bróż M. 2008. Contamination of tap water with products of iron corrosion. Gaz, Woda i Technika Sanitarna, 4, 17-20. (in Polish)

13. Wolska M., Mołczan M. 2015. Stability assessment of water introduced into the water supply network. Ochrona Środowiska, 37(4), 51-56. (in Polish)

14. Zymon W. 2007. The use of the aeration process for the desorption of carbon dioxide from surface water: a case study. Ochrona Środowiska, 29(4), 65-68. (in Polish)

15. Żaba J. 2003. Illustrated dictionary of rocks and minerals. Videograf II, Katowice. (in Polish)

Pracę dofinansowano ze środków Wojewódzkiego Funduszu Ochrony Środowiska i Gospodarki Wodnej w Lublinie. 